\title{
The Short and Long Term Performance of Initial Public Offerings in the Cyprus Stock Exchange
}

\author{
Dimitrios Gounopoulos*, Christos Nounis**, Paris Stylianides*** \\ *School of Management, University of Surrey, Guildford, Surrey, GU2 8DA, UK \\ **Department of Economics, University of Athens, Athens, 10559, Greece \\ ${ }^{* * *}$ Cass Business School, City University, London, EC1Y 8TZ, UK
}

\begin{abstract}
This study examines the price performance of initial public offerings (IPOs) in the Cyprus Stock Exchange during the period 1999-2002. It examines the differences between the listing price of IPOs and their equilibrium market prices at the end of the first day, sixth, twelfth, twenty-fourth and thirty-sixth month for 75 new listed companies. From the derived results it is evident that Cypriot IPOs have extremely large positive initial returns, especially on the end of the first trading day. Long term results, not taking into account the first day returns are much lower and sometimes even negative.

The first day underpricing phenomenon forces to search for possible factors, which may have caused it. Different variables used in similar international studies were adopted to test the Cypriot case. Our research shows that positive initial returns, amongst other factors, may have been affected by increase in the General Index of the Stock Exchange between the last day of public offerings' period and the first trading day (time lag), the reputation of the companies underwriters, the firms issue size and the companies history. It is also evident that our sample was affected by the extraordinary stock exchange conditions that prevailed during the specified period, which is examined. The intriguing Cyprus Stock Exchange behaviour is further examined by looking into its investment, parallel and alternative primary markets.
\end{abstract}

Keywords: Initial Public offerings, Underpricing, Long-term performance, market efficiency, underwriters

JEL classification code: G14, G12 


\section{Introduction}

The $29^{\text {th }}$ of March 1996 is a symbolic date for the Cyprus economy. The Cyprus Stock Exchange started its operations as a legal entity in the form of a public corporation body. Since then many firms decided to go public in order to raise capital from institutional and private investors and expand their activities.

Taking a firm public is a significant turning point in the life of a firm with serious wealth implications for the existing shareholders. The success of the public listing depends among other factors, on the ability to determine an offering price that represents fairly the intrinsic value of the firm. To avoid certain uncertainties involved in the public sale of their securities, firms retain underwriters who undertake the risk of pricing and selling new securities. Underwriter's main role is to make sure that the issue will be fully absorbed by the public with the highest possible price.

The international evidence on the initial public offerings has focused on the study of two anomalies. Firstly, new issues are offered to the investors in prices much lower than the after aftermarket stabilization. Despite the use of underwriters the issue price do not represent the expected by market price and new shareholders make profits in the back of the old. Secondly, the long-term performance of IPOs seems to be poor and the returns to the initial investors proves to be negative.

Using as fuel the strong international evidence for initial underpricing and the negative long-term returns there will be an effort by the present study to search the price behavior of new issues and explore if that phenomenon finds application also in the case of Cypriot IPOs.

Some of interesting features of this market are the followings. First, Cypriot is the smallest market the international evidence has ever searched. With a population of less than one million and more than 250 listed firms this market combines unique characteristics. Second, the time lag between issue day and first day of trading is high enough to delay entrance in the stock exchange up to three weeks from the time of sale to the investors. The last increases the uncertainty of the investors and may affect pricing of IPOs and flotation costs. Third, opposite to the IPOs in the U.S. which are priced very 
close to the offering date, Cypriot newly listed firms are priced few weeks before causing higher pricing and waiting risk.

The structure of the remainder of this paper is as follows. In section 2 the reasons for underpricing are clearly stated and the international literature is described. Section 3 examines the legislative framework for Cyprus Stock Exchange. Section 4 presents, the methodology, regression model specifications, determinants of the model and sample characteristics. The initial and aftermarket performance of the sample is examined in section 5 . The paper concludes with a brief summary in section 6 .

\section{Literature Review}

\subsection{Reasons for underpricing}

A number of reasons have been raised for the new issues underpricing phenomenon and the long-term underperformance with different theories focusing on various aspects of the relation between investors, issuers and underwriters taking the firms public. The main theories are reviewed and presented in the following lines.

Rock (1986) introduced a model, which provides the explanation for the information asymmetry between the investors. It was named as 'winners curse hypothesis' and symbolizes the win that informed investors achieve as they are rewarded the most underpriced IPOs. Uninformed investors are the losers, as they do not know which issues will be underpriced and so they are allocated large fraction of overpriced shares. Beatty and Ritter (1986), Barry and Jennings (1993) support this hypothesis by providing evidence from U.S. market.

Tinic (1988) states that firms underprice IPOs to decrease the probability of lawsuit by investors. Indication of a legal liability can create negative impression for an IPO and can cause the failure of the issue. Drake and Vetsuypens (1993) examined 93 IPOs that were involved in lawsuits and find that they were not affected at all by any negative publicity. Thus they reject lawsuit avoidance hypothesis arguing that litigation risks arise after the initial offering.

Allen and Faulhaber (1989), Welch (1989) and Grinblatt and Hwang (1989) consider underpricing of IPOs as a tool used by firms to signal their quality. Signaling theory mainly targets in seasoned offerings as the more a firm underprice its listing price, 
signaling its high value, the more likely it is that it will reissue. Investors through underpricing become aware of the true value of firm so the market expects 'less money on the table' in the future subscriptions. Su and Fleisher (1997), and Hammed and Lim (1998) support signaling theory for Chinese and Singapore IPO markets. On the other hand Garfinkel (1993) and Espenlaub and Tonks (1998) suggests that underpricing has little signaling effect on the seasoned offerings.

Aggarwal and Rivoli (1990) and Ritter (1991) based on the long term underperformance of the market, report that excess initial returns are caused by overvaluation of IPOs by investors and the presence of fads in the early aftermarket. The fads hypothesis supports that IPOs are priced well and it is the investors' enthusiasm that overvalues the IPOs. Aggarwal et al (1993) and Levis (1993) provide international evidence which support the fads hypothesis. On the other hand Allen et al (1993) and Huang (1999) states that it is not possible to support the fads hypothesis.

Welch (1992) presents a model in which potential investors pay attention not only to their information but also in the behaviour of the other investors. If an individual has favorable information about an IPO and sees that no one else wants to buy he may change his opinion and decide not to go ahead with a bid. This is the point that underwriter in an agreement with the issuer decide to underprice the IPO and induce a cascade in which all potential investors want to buy.

Booth and Chua (1996) and Brennan and Franks (1997) support the ownership dispersion hypothesis. They argue that firms are willing to underprice in order to have a diffuse ownership base and create a liquid market for their shares. Underpriced IPOs generate excess demand and create a large number of small shareholders. This is crucial for all IPOs as they aim for high participation of public in order to make difficult for outsiders to challenge management.

\subsection{International evidence on the short and long run performance of IPOs}

There are many studies in empirical literature on IPOs concentrated mainly on the issues of short-term underpricing and long-term underperformance. Table 1 gives a summary of the most recent findings in a number of countries around the world. In some cases due to 
a numerous number of studies for the same market we had to use the accumulated results reported in Loughran et al (2006) updated version.

Researchers have extensively examined the U.S. IPO market over the last decades. The last update by Loughran et al (2006) in 15,333 IPOs that were listed in the period 1960-2005 reveals first day returns of 18.1\%. Similar to this finding Ritter and Welch (2002) report initial returns of $18.8 \%$ in the United States from 1980-2001. Opposite to the short-term overperformance, evidence on long-term in the U.S. suggests underperformance. Loughran and Ritter (1995) find the three-year holding period return on a sample of 4,735 IPOs to be $-20 \%$. The aftermarket underperformance in the United States is confirmed by Ritter and Welch (2002) who indicated in their study that the long term returns were negative for an investor buying new titles in the offer price period.

A look in other world leading markets i.e. Canada, France, Germany, Japan, UK shows similar trend. Crossing the border to the States we meet Canada. Summary by Loughran et al (2006) in 540 Canadian IPOs indicates low initial returns of only 7\%. Despite the low level of underpricing, Kooli \& Suret (2002) show in their study that long term return to Canadian investors are negative at $16.86 \%$. On the other side of the Atlantic there is France, which experiences slightly higher initial returns at $11.6 \%$ but Loughran et al (2006) summarizing existent studies show that the long term underperformance is only $4.8 \%$. The last figure highlights that the France market is reliable for the long-term oriented investors, as they will not loose the invested money during the offer price period.

Ljungqvist (1997) and Rocholl (2004) combined results for German market show initial returns of $31.1 \%$ for 571 IPOs while Ljungqvist in a smaller sample find long term returns of $-12.1 \%$. Using a cumulative sample from 6 different studies, Loughran et al (2006) report overwhelming evidence that Japanese IPOs overperform in the short term by $28.4 \%$. Similar to other developed countries, Cai and Wei (1997) in a study which covers 19 years period document negative three years long term returns by $27 \%$. Moving to the UK market, study of a large sample of 3,122 IPOs issued in the period 1959-2001, indicates average initial returns of $17.4 \%$. Long term investment in IPOs seems worthless even in the UK market as Levis (1993) find long term underperformance by $8.1 \%$ 
Table 1: International Empirical Evidences

\begin{tabular}{|c|c|c|c|c|c|}
\hline Country & Studies & Period & Sample & $\begin{array}{l}\text { Short term } \\
\text { returns }\end{array}$ & $\begin{array}{l}\text { Long term } \\
\text { returns }\end{array}$ \\
\hline Australia & $\begin{array}{l}\text { Lee, Taylor and Walter } \\
(1996)\end{array}$ & 1976-1995 & $381 / 266$ & $12.1 \%$ & $-51 \%$ \\
\hline Austria & Ausenegg (2000) & $1965-2002$ & $83 / 57$ & $6.3 \%$ & $-46.5 \%$ \\
\hline Brazil & Aggarwal et al (1993) & 1979-1990 & 62 & $78.5 \%$ & $-47 \%$ \\
\hline \multirow[t]{2}{*}{ Canada } & Loughran et al (2006) & $1971-2002$ & 540 & $7.0 \%$ & \\
\hline & Kooli \& Suret (2002) & 1991-1998 & 445 & & $-16.86 \%$ \\
\hline Chile & Aggarwal et al (1993) & 1982-1990 & $55 / 28$ & $8.8 \%$ & $-23.7 \%$ \\
\hline Finland & Keloharju (1993) & 1984-1989 & $99 / 79$ & $10.1 \%$ & $-21.1 \%$ \\
\hline France & Loughran et al (2006) & $1983-2000$ & $571 / 87$ & $11.6 \%$ & $-4.8 \%$ \\
\hline Germany & Ljungqvist (1997), Rocholl & $1983-2000$ & $545 / 145$ & $31.1 \%$ & $-12.1 \%$ \\
\hline Greece & Thomadakis et al (2006) & 1994-2002 & 254 & $42.12 \%$ & $-92.93 \%$ \\
\hline \multirow[t]{2}{*}{ Hong Kong } & Loughran et al (2006) & $1980-2001$ & 857 & $17.3 \%$ & \\
\hline & McGuiness (1993) & 1980-1990 & 72 & & $-18.3 \%$ \\
\hline Hungary & Lyn and Zychowicz (2003) & 1991-1998 & 33 & $15.12 \%$ & $19.59 \%$ \\
\hline \multirow[t]{2}{*}{ Japan } & Loughran et al (2006) & $1970-2001$ & 1689 & $28.4 \%$ & \\
\hline & Cai and Wei (1997) & $1971-1990$ & 172 & & $-27.0 \%$ \\
\hline Korea & Dhatt et. al. (1993) & $1980-1990$ & 347 & $78.01 \%$ & $4.64 \%$ \\
\hline \multirow[t]{2}{*}{ Malaysia } & Isa \& Yong (2001) & 1980-1998 & 401 & $104.1 \%$ & \\
\hline & Ahmad-Zaluki et al (2004) & $1990-2000$ & 454 & & $-8.16 \%$ \\
\hline \multirow[t]{2}{*}{ New Zealand } & Loughran et al (2006) & 1979-1999 & 201 & $23.0 \%$ & \\
\hline & Firth (1997) & 1979-1987 & 143 & & $-10.0 \%$ \\
\hline Poland & Lyn and Zychowicz (2003) & 1991-1998 & 103 & $54.45 \%$ & $57.17 \%$ \\
\hline \multirow[t]{2}{*}{ Singapore } & Loughran et al (2006) & $1973-2001$ & 441 & $27 \%$ & \\
\hline & Hin \& Mahmood (1993) & 1976-1984 & 45 & & $-9.2 \%$ \\
\hline \multirow[t]{2}{*}{ Spain } & Ansotegui et. al. (2000) & 1986-1998 & 99 & $10.7 \%$ & \\
\hline & Alvarez et. al. (2001) & 1987-1997 & 41 & & $-24.19 \%$ \\
\hline \multirow[t]{2}{*}{ Sweden } & Loughran et. al. (2006) & 1980-1998 & 332 & $30.5 \%$ & \\
\hline & Loughran et. al. (1994) & 1980-1990 & 162 & & $1.2 \%$ \\
\hline Switzerland & Loughran et. al. (2006) & $1983-2000$ & $120 / 34$ & $34.9 \%$ & $-6.1 \%$ \\
\hline \multirow[t]{2}{*}{ Turkey } & Loughran et. al. (2006) & $1990-2004$ & 282 & $10.8 \%$ & \\
\hline & Yilmaz \& Bildik (2005) & $1990-2000$ & 234 & & $-84.5 \%$ \\
\hline \multirow[t]{2}{*}{ U.K. } & Loughran et al (2006) & $1959-2001$ & 3,122 & $17.4 \%$ & \\
\hline & Levis (1993), & $1980-1988$ & 712 & $14.30 \%$ & $-8.1 \%$ \\
\hline \multirow[t]{2}{*}{ U.S. } & Loughran et. al. (2006) & $1960-2001$ & 15,333 & $18.1 \%$ & \\
\hline & Loughran \& Ritter (1995) & $1970-1990$ & 4,753 & & $-20.0 \%$ \\
\hline
\end{tabular}


In the emerging market area, many studies have been done. The most recent ones by Lyn and Zychowicz (2003) for Poland, Loughran et al (2006) for Turkey and Thomadakis, et al (2006) for Greek IPO markets report average initial returns of $54.45 \%, 10.8 \%$ and $42.19 \%$ respectively. The long run performance analysis in these three European markets shows overperformance of $57.17 \%$ for Poland and underperformance for Turkey and Greece.

\section{The stock market and new issue process in Cyprus}

\subsection{The legislative Framework}

The CSE council, in the framework of upgrading the CSE services and its efforts for continuous harmonization with international capital markets completed a major development program. As of the $6^{\text {th }}$ of September 2004 there were the following four new markets: Main Market, Parallel Market, Alternative Market and Investment Companies Market.

Regulations of Cyprus Stock Exchange specify the ways of getting a listing for all IPOs. Issuers can list securities on the Stock Exchange in one of the following ways: By offer for sale - through the placement of securities that have already been public, by public offer for sale to the public, by public offer for subscription for the purchase of titles and by private placement - an offer is made to specific investors for the sale of shares.

CSE establishes basic (minimum) requirements for obtaining a listing. However each company that seeks a listing must satisfy some basic requirements, the most important of which are the followings. The expected market value of the proposed issue must be in excess of 2 million Cypriot Lira, the issuer must have published audited accounts for at least the three years preceding the application, companies should have been established with the sole purpose of financing a large project and it is not allowed for any shareholder to control either direc.tly or indirectly. Finally more than seventy per cent of the share capital and a percentage of at least twenty five per cent of the share capital must be satisfactorily dispersed to the public at large.

A company who wishes to enlist its stock in the Main Market must abide to all laws governing the 'general enlistment of new stock' in the Cyprus Stock Exchange. It 
must also abide to the following special requirements: At least $25 \%$ of the shares which will be issued must be held by the general public and by 1000 legal or non-legal entities, which none have a share amount which exceeds $2 \%$ of the share total. No shareholder must control directly or indirectly an amount exceeding $70 \%$.

\section{Methodology, sources and data}

\subsection{Measures of initial, short and long-term performance}

Using the term initial we calculate the returns of the IPOs in the end of first day of trading. Short-term performance includes the returns in the end of second day of trading while long-term performance covers a period up to three years. We measure the level of underpricing of IPOs listed on the CSE boards using the conventional method, where the raw initial return (RIR) on the first day of trading is calculated as follows:

$$
\operatorname{RIR}_{i, t}=\frac{P_{i, 1}-P_{i, 0}}{P_{i, 0}}
$$

where $\mathrm{P}_{\mathrm{i}, 1}$ is the price at the end of the first day of trading and $\mathrm{P}_{\mathrm{i}, 0}$ is the offering price.

The initial return is adjusted for market changes, taking into account movements of the Cyprus Stock Exchange General Index (CSEGI) between the closing date and the first day of trading. Raw initial return, which is calculated by the above equation, does not have a time lag between the closing day and the first day of trading in the stock exchange. During this period, many changes in market conditions may occur. As a result the initial return measured may be a result of changes in market conditions. So the raw initial return is adjusted for market changes and variances.

The market adjusted initial return is calculated as follows:

$$
\operatorname{MAIR}_{t}=\left[\frac{P_{i, 1}-P_{i, 0}}{P_{i, 0}}-\frac{M I_{i, 1}-M I_{i, 0}}{M I_{i, 0}}\right]^{1}
$$

where $\mathrm{MI}_{\mathrm{i}, 1}$ is the General index price at the end of the IPO first day of trading and $\mathrm{MI}_{\mathrm{i}, 0}$ is general index price at the last day of IPO public offering period.

\footnotetext{
${ }^{1} \mathrm{MAIR}=$ Market - adjusted (excess) initial return, $\mathrm{MI}_{\mathrm{i}, 1}$ and $\mathrm{MI}_{\mathrm{i}, 0} \mathrm{ASE}$ Composite index on day 1 and offer prices setting date.
} 
The long-term return is computed by measuring the returns of each offering for months 6 and years 1 through 3 . The market adjusted returns for each offering $i$ is measured as the return from the offering price in a first set of results and from first trading day's closing price in a second set to the calendar day, where $t$ is 6 months and 1, 2 or 3 years minus the equivalent market returns over the same period.

The excess return for company $i$ in month $t$ is defined as:

$$
\mathrm{AR}_{\mathrm{it}}=\mathrm{r}_{\mathrm{it}}-\mathrm{r}_{\mathrm{bt}}(3)
$$

Where $r_{i t}$ is the raw return for company $i$ in month $t$ and $r_{b t}$ is the benchmark return in month t. It follows the calculation of the average benchmark adjusted return on a portfolio of $\mathrm{N}$ stock for month $\mathrm{t}$.

$$
A A R_{t}=\frac{1}{N} \sum_{i=1}^{n} A R_{i t}
$$

The cumulative adjusted returns are then calculated as the summation of the average abnormal returns. This is based on the arguments proposed by Barber and Lyon (1997). The evaluation of the long-run performance will be held in the aid of this measure.

$$
C A R_{q, s}=\sum_{t=q}^{s} A A R_{t}
$$

To investigate if certain characteristics influence the short and long term of IPOs we introduce the regression model introduced in the following section.

\subsection{Regression model specification}

The following regression equations are used to assess the determinants of shortterm outperformance and long-term underperformance of IPOs:

Return ${ }_{\mathrm{i}}=\alpha_{0}+\alpha_{1} \mathrm{TLAG}_{\mathrm{i}}+\alpha_{2} \mathrm{SIZE}_{\mathrm{i}}+\alpha_{3} \mathrm{AGE}_{\mathrm{i}}+\alpha_{4} \mathrm{UND}_{\mathrm{i}}+\alpha_{5} \mathrm{HC}_{\mathrm{i}}+\alpha_{6} \mathrm{OWN}_{\mathrm{i}}+\varepsilon \mathrm{i}$ 
TLAG $\mathrm{G}_{\mathrm{i}}$ is the period between the announcement of the offer price and the first day of trading. Loughran et al (1994, Updated 2003) suggest that the longer the time period between setting the offer price and listing, the greater will be the underpricing level, conditional on the offer not being withdrawn. Chowdhry and Sherman (1996) report that the time between the IPO announcement day (that is, the day of prospectus) and the first day of market trading affects the underpricing level. Su and Fleisher (1998) find a positive relationship between the average initial returns of IPOs and the time gap between issue and flotation dates in their sample for the Shanghai Stock Exchange. The longer the time of flotation, the more uncertainty is associated with the offer. However, if uncertainty about the IPO valuation and listing increases due to unnecessary delay of subscription and flotation, investors would incur lower costs as a result of relatively low subscription.

Size $_{\mathrm{i}}$ is the magnitude of the offering, measured as the product of the number of shares being offered and the offer price issued. The size characteristics have been documented extensively as important determinants of stock returns (Banz (1981); Chan et al., (1991); Daniel and Titman, (1997); Daniel et al., (2001); Fama and French, (1992); Davis et al., (2000); Davis, (1994); Lakonishok et al., (1994); Loughran and Ritter, (1995)). Literature documents that if smaller firms tend, on average, to be more risky, then first day returns are expected to be bearish related to firm size. In general, larger firms have a higher association with a larger flow of external information sources than smaller firms. The difference between those amounts of the information revealed when a data item is disclosed and the market's expectation is inversely related to firm size.

$\mathrm{AGE}_{\mathrm{i}}$ is the operating history of a firm prior to going public. Ritter (1984), Clarkson and Merkley (1994), Nazir and Zin (1998), and Kaneko and Pettway (2003) support that firms are expected to have lower ex-ante uncertainty compared to younger firms because older firms have more public information available than younger firms. Companies that are older and have a longer operating history have more information available to the public. Younger firms, especially companies with a lower operating history provide lower information to the public.

$\mathrm{UND}_{\mathrm{i}}$ is a dummy variable taking a value of one (1) if the underwriter is one of the big five investment Banks, otherwise $\mathrm{UND}_{\mathrm{i}}$ is coded zero (0). Reputable underwriters 
are categorized according to the combination of the following three parameters: (a) The fee rate as a percentage of amount raised (b) the number of public offerings each of them has dealt with during the period of my sample (c) and the total market capitalization of the IPOs listed. However, taking in consideration all the above factors we conclude that 5 banks/syndicates (CISCO, Laiki Investment, CLR Securities, Severies and Athienitis and Sharelink) among twenty-five are the prestigious underwriters in the Cyprus Market. Those five underwriters have listed more than $70 \%$ of the total market capitalization and number of listed firms in CSE.

Beatty and Ritter (1986), Beatty and Welch (1996) and Carter et al (1998) report that a prestigious underwriter can help the issuer to get a higher price for its shares, which is to accept a smaller IPO discount than normal. Thus, the reputable underwriter's goal is to set the issue price to maximize profits earned from the IPO. Nanda and Yun (1997) and Chemmanur and Paeglis (2005) specify that underwriters should be very careful because their reputation could be easily harmed if an IPO is over priced and yields negative first day and long term returns.

$\mathrm{HC}_{\mathrm{i}}$, is a dummy variable equal to 1 for hot periods and 0 if it is a cold. Hot issue periods are those months with an average initial return greater than the half, whilst cold period issues are identified as those with an average initial return of less than the half. Hot markets are characterized by great uncertainty and issues have to be discounted even more than usual to attract uninformed investors. Cold markets occur when there is comparative less uncertainty and therefore less discounting. Ibbotson and Jaffe (1975), Ibbotson et al (1986), Affleck-Graves (1996), Lowry and Schwert (2002) Benveniste et al (2003), Derrien and Womack (2003), and Kaneko and Pettway (2003) measure the relationship of returns with the market movements to determine the impact of "hot' and "cold" markets upon the level of underpricing and stocks underperformance. They suggest that companies should choose the cold issue market to go public so that they can gain from higher prices of hot periods.

$\mathrm{OWN}_{\mathrm{i}}$, measure the percentage of shares retained by pre IPO shareholders. Allen and Faulhaber (1989) report that we can see the best information about a company's future prospects by the fraction of shares given by owners after the IPO. Grinblatt and Hwang (1989), Hansen and Torregrosa (1992) extend the above study and find an inverse 
relationship between the proportion of shares given by owners and the initial average returns. Hingorani et al (1997) in a study for the Czech firms suggest that low given holdings by insiders can signal that the firm possesses valuable assets. According to them, "insiders by virtue of their international advantage are more likely to own shares of companies when they expect the firm to generate high returns".

\subsection{Sample}

The data collected cover the period of January 1999 to December 2002 and include only listings of common stock in the Cyprus Stock Exchange. Basic sources of information have been the Annual Statistical Bulletins and Fact Books for information as Offer and listing dates and prices, and the capital raised. Daily statistical bulletins of CSE and datastream were used to collect IPOs and General Index closing prices.

As seen in Table 2 the total number of newly listed companies during the period 1999-2002 were 114. Most listings occurred in 2000 with 64 IPOs and a staggering $56.14 \%$ of the total amount of issues. This is mostly due to the fact that during the end of 1999 and the beginning of 2000 there was stock exchange 'frenzy' with prices reaching unrealistic values. It was later consider a scandal with various legal implications.

Table 2: Allocation per year of IPOs in CSE

\begin{tabular}{lcccl}
\hline \multicolumn{2}{c}{ Number of IPOs per year } & $\mathbf{1 / 1 9 9 9 - 1 2 / 2 0 0 2}$ & \multicolumn{2}{c}{ Our sample 1/1999-12/2002 } \\
\hline YEAR & Number of Issues & $\%$ of total & Number of issues & $\%$ of total \\
1999 & 13 & $11,40 \%$ & 9 & $12 \%$ \\
2000 & 64 & $54,14 \%$ & 37 & $49.33 \%$ \\
2001 & 27 & $23,68 \%$ & 20 & $26.66 \%$ \\
2002 & 10 & $8,77 \%$ & 9 & $12 \%$ \\
\hline TOTAL & 114 & $100,00 \%$ & 75 & $100,00 \%$ \\
\hline
\end{tabular}

The CSE committee in an effort to harmonize with international capital markets followed a restructure on the classification of newly listed firms. The IPOs were listed in four markets on CSE, the Main, Parallel, Alternative and Investment. The decision on market 
classification was taken on $6^{\text {th }}$ September 2004 based on FTSE International and this has been the reason that we do not study this variable as a criterion for underpricing.

Table 3 reports the partition of IPOs among various sectors. Of the 114 IPOs, 27 are classified as 'Other Companies', followed by 'Approved Investment' with 24, and 'Trading Companies' with 13. Banking sector does not include any new issue for the period 1999-2002 while there are only two IPOs listed in the 'insurance sector'.

Table 3: Classification of Initial Public Offerings in CSE by year, 1999-2002

\begin{tabular}{lrrrrc}
\hline Industry & 1999 & 2000 & 2001 & 2002 & Total \\
\hline Approved Investment & 3 & 19 & 2 & 0 & $\mathbf{2 4}$ \\
Construction & 0 & 4 & 0 & 4 & $\mathbf{8}$ \\
Financial Services & 2 & 2 & 4 & 0 & $\mathbf{8}$ \\
Fish Culture & 1 & 2 & 0 & 0 & $\mathbf{3}$ \\
Hotels & 0 & 4 & 2 & 0 & $\mathbf{6}$ \\
Information Technology & 0 & 4 & 0 & 0 & $\mathbf{4}$ \\
Insurance & 0 & 2 & 0 & 0 & $\mathbf{2}$ \\
Other companies & 4 & 11 & 9 & 3 & $\mathbf{2 7}$ \\
Trading Companies & 2 & 7 & 3 & 1 & $\mathbf{1 3}$ \\
Tourism Companies & 0 & 2 & 2 & 0 & $\mathbf{4}$ \\
Total & $\mathbf{1 3}$ & $\mathbf{6 4}$ & $\mathbf{2 7}$ & $\mathbf{1 0}$ & $\mathbf{1 1 4}$ \\
\hline
\end{tabular}

During the preparation of the database for the new listing in the CSE there were some constraints with specific IPOs with a result to exclude them from our sample. Specifically four IPOs that went public in year 1999 were eliminated from the sample due to lack of information. Moving to next year four IPOs that were listed during 2000 were excluded later from trading with a result of losing closing prices for specific future points creating difficulties in the calculation of long-term returns. Six IPOs of the same year were listed by offer for sale - through the placement of securities that have already been public - without issuing new shares and four IPOs were listed by private placement - an offer has been made to specific investors for the sale of shares. There are thirteen firms, which do not present detailed financial statement for the year before being an IPO because they were established only few months before going public.

There are three IPOs of year 2001 that were listed through the placement of securities that have already been public and one that offered shares for free in existing 
shareholders. Three firms that were listed during 2002 did not have enough data. Finally, we excluded outliers i.e. four firms that were listed throughout the period of this study (Logicom Public Ltd, which was listed on the $4^{\text {th }}$ of January 2000 had an issue price of CYP0.5 and a first day closing price CYP6.5. The raw first day return was 1300\%). Summarizing there is a sample of 75 IPOs for the period January 1999 - December 2002, which includes 9 IPOs for 1999, 37 IPOs for 2000, 20 IPOs for 2001 and 9 IPOs for 2002.

\section{Empirical findings}

\subsection{Initial underpricing and long-term performance}

Table 4 summarizes the initial $\left(1^{\text {st }}\right.$ day) and short-term performance $\left(2^{\text {nd }}\right.$ day $)$ as well as the aftermarket performance (6 months, 1-2-3 years) for Cyprus Stock Exchange. Panel A shows raw and adjusted initial return of $100.49 \%$ and $108.63 \%$ respectively. It is during the middle of 1999 and the beginning of 2000 that CSE experienced these extraordinary returns, which indicate that the special conditions, which existed, had a strong influence on the returns. This means, in practical terms, that investors who acquired stock through offering price period and held them until the end of the first day of trading would earn very high returns.

By looking at the long-term results, the negative raw returns start eighteen months after going public. However, the longer run returns in two years time is $-50.14 \%$ and to a staggering $-66.31 \%$ after three years. The mean adjusted returns have a positive $39.08 \%$ in the first year, remains positive in the end of the second year with $1.72 \%$ and gets negative in the third year with $-4.96 \%$.

Blue Island Holding PLC made a staggering 911.22\% first day adjusted returns, while Caramondani Bros Ltd and Unifast Finance \& Investments Ltd made a 252.31\% and $317.76 \%$ one year adjusted returns respectively. On the other hand we have companies like A.L.Pro Choice Group Public Ltd, having negative first day initial returns of $-45.55 \%$ and K.Kithreotis Public Ltd who was listed in April 2002, having six months negative returns of $-62 \%$. Those cases were excluded from our sample as outliers.

It is clearly visible that the 'buy and sell' strategy in the short term seems to be much better from the 'buy and hold' strategy in the long term. This finding can be a 
motivation for shareholders to flip their shares and get the profit than hold them and start losing in the long term.

Table 4: Raw Returns for Initial Public Offerings from the Cyprus Stock Exchange - Time Period 1999-2002

\section{PANEL A:}

IPO returns for period of 6 months, 1-2-3 Years in comparison with the offer price

\begin{tabular}{|c|c|c|c|c|c|c|}
\hline RETURN OF & $\begin{array}{c}\text { MEAN } \\
\text { RETURN } \\
(\%)\end{array}$ & $\begin{array}{c}\text { STANDARD } \\
\text { DEVIATION } \\
(\%)\end{array}$ & $\begin{array}{c}\text { NUMBER OF } \\
\text { OBSERVATIONS }\end{array}$ & $\begin{array}{l}\text { MEDIAN } \\
(\%)\end{array}$ & $\begin{array}{c}\text { MINIMUM } \\
\text { RETURN } \\
(\%) \\
\end{array}$ & $\begin{array}{c}\text { MAXIMUM } \\
\text { RETURN } \\
(\%) \\
\end{array}$ \\
\hline \multicolumn{7}{|c|}{ RAW RETURNS } \\
\hline 1st day & 100.49 & 227.09 & 75 & 7.21 & -46 & 1200 \\
\hline 2nd day & 100.98 & 223.73 & 75 & 8.40 & -44 & 1070 \\
\hline 6 months & 52.86 & 204.44 & 75 & -9.04 & -86.50 & 1070 \\
\hline 12 months & 3.86 & 120.35 & 75 & -30.50 & -95.90 & 570 \\
\hline 24 months & -50.14 & 48.09 & 75 & -65.10 & -98.83 & 184 \\
\hline 36 months & -66.31 & 33.92 & 75 & -74.35 & -99.56 & 121 \\
\hline \multicolumn{7}{|c|}{ EXCESS OR ADJUSTED RETURNS } \\
\hline 1st day & 108.63 & 226.02 & 75 & 18.24 & -48.60 & 1209 \\
\hline 2nd day & 108.98 & 223.73 & 75 & 18.73 & -47.00 & 1080 \\
\hline 6 months & 32.47 & 86.73 & 75 & 50.87 & -428.57 & 122.23 \\
\hline 12 months & 39.08 & 97.67 & 75 & 23.68 & -308.48 & 532.26- \\
\hline 24 months & 1.72 & 61.37 & 75 & -0.40 & -383.61 & 160.14 \\
\hline 36 months & -4.96 & 43.42 & 75 & -7.35 & -157.62 & 187.62 \\
\hline
\end{tabular}

PANEL B

IPO returns for period of 6 months, 1-2-3 Years in comparison with $1^{\text {st }}$ day of trading

\begin{tabular}{|c|c|c|c|c|c|c|}
\hline RETURN OF & $\begin{array}{l}\text { MEAN } \\
\text { RETURN } \\
\text { (\%) }\end{array}$ & $\begin{array}{c}\text { STANDARD } \\
\text { DEVIATION } \\
(\%)\end{array}$ & $\begin{array}{c}\text { NUMBER OF } \\
\text { OBSERVATIONS }\end{array}$ & $\begin{array}{l}\text { MEDIAN } \\
\text { (\%) }\end{array}$ & $\begin{array}{l}\text { MINIMUM } \\
\text { RETURN } \\
(\%)\end{array}$ & $\begin{array}{l}\text { MAXIMUM } \\
\text { RETURN } \\
(\%)\end{array}$ \\
\hline \multicolumn{7}{|c|}{ RAW RETURNS } \\
\hline 6 months & -17.88 & 65.35 & 75 & -31.91 & -84.70 & 425.42 \\
\hline 12 months & -35.26 & 68.74 & 75 & -43.5 & -96.57 & 467.49 \\
\hline 24 months & -62.85 & 39.30 & 75 & -73.35 & -98.79 & 140.67 \\
\hline 36 months & -73.10 & 27.82 & 75 & -79.73 & -99.30 & 33.89 \\
\hline \multicolumn{7}{|c|}{ EXCESS OR ADJUSTED RETURNS } \\
\hline 6 months & -0.13 & 65.35 & 75 & -31.91 & -84.70 & 425.42 \\
\hline 12 months & -3.68 & 59.89 & 75 & -0.10 & -322.279 & 132.474 \\
\hline 24 months & -7.42 & 32.73 & 75 & -11.34 & -77.70 & 100.742 \\
\hline 36 months & -15.36 & 37.46 & 75 & -13.68 & -203.725 & 96.43 \\
\hline
\end{tabular}

Panel B of Table 3 reports the short and longer-term returns excluding the first day returns and shows that from the first six months, the return achieved on the first trading day has already eroded. In particular, the mean adjusted returns on the six month period is $-0.13 \%$ and then constantly decreases to $-3.68 \%$ after 12 months, $-7.42 \%$ after twenty-four months and $-15.36 \%$ after thirty-six months. Triaina Investments Public Co, 
had a $425.42 \%$ six-month raw return and a 104\% six month adjusted return, a result clearly contracting the general negative trend.

The previous results provide a general idea for the extent of short and long-term returns. Those results require carefully study, as during the examined period they were in effect special Stock Exchange financial circumstances. Specifically, the study of General Index shows a significant increase from the middle of 1999 to half of 2000. This is internationally known as the 'bubble' effect and it forces on a more analytical study in annual base.

Table 5 classifies IPOs annually and presents the initial and long-term returns. Panel A indicates significantly statistical and hyperbolic initial returns of $491.62 \%$ to all those institutions/individuals that invested during the offer price period for 1999 IPOs. High returns seem to remain even one year after going public. The level of underpricing for one year $\left(\mathrm{CAR}_{1,256}\right)$, for 2 years $\left(\mathrm{CAR}_{1,312}\right)$ and for three years $\left(\mathrm{CAR}_{1,768}\right)$ after going public is $128.38,-2.86$ and -13.05 respectively. Opposite to the previous result the investors who bought shares in the end of first day of trading had a big loss even one year after listing.

Table 5: Performance categorized by Year if Issuance for IPOs in 1999-2002

\begin{tabular}{|c|c|c|c|c|c|}
\hline RETURN OF & $\begin{array}{l}\text { ADJUSTED } \\
\text { MEAN } \\
\text { RETURN } \\
(\%)\end{array}$ & $\begin{array}{l}\text { MEDIAN } \\
(\%)\end{array}$ & $\begin{array}{c}\text { NUMBER OF } \\
\text { OBSERVATIONS }\end{array}$ & $\begin{array}{c}\text { ADJUSTED } \\
\text { MEAN RETURN } \\
(\%) \\
\left(1^{\text {st }} \text { trading day }\right)\end{array}$ & $\begin{array}{c}\text { MEDIAN } \\
(\%) \\
\left(1^{\text {st }} \text { trading day }\right)\end{array}$ \\
\hline \multicolumn{6}{|c|}{ Panel A: Year 1999} \\
\hline $\mathrm{CAR}_{1,1}$ & 491.62 & 498.54 & 9 & & \\
\hline $\mathrm{CAR}_{1,256}$ & 128.38 & 132.00 & 9 & -64.36 & -25.29 \\
\hline $\mathrm{CAR}_{\mathbf{1 , 5 1 2}}$ & -2.86 & 14.34 & 9 & -15.71 & -12.62 \\
\hline $\mathrm{CAR}_{1,768}$ & -13.05 & 0.24 & 9 & -34.35 & -12.95 \\
\hline \multicolumn{6}{|c|}{ Panel B: Year 2000} \\
\hline$\overline{\mathrm{CAR}_{1,1}}$ & 83.60 & 31.20 & 37 & & \\
\hline $\mathbf{C A R}_{1,256}$ & 47.51 & 41.74 & 37 & 15.38 & 12.64 \\
\hline $\mathrm{CAR}_{1,512}$ & 18.10 & 12.00 & 37 & 4.01 & -2.39 \\
\hline $\mathrm{CAR}_{1,768}$ & 15.48 & 4.88 & 37 & 3.00 & -1.36 \\
\hline \multicolumn{6}{|c|}{ Panel C: Year 2001} \\
\hline $\mathrm{CAR}_{1,1}$ & -0.86 & -1.55 & 20 & & \\
\hline $\mathrm{CAR}_{1,256}$ & -6.02 & -6.03 & 20 & -7.23 & -8.71 \\
\hline $\mathrm{CAR}_{1,512}$ & -20.49 & -23.21 & 20 & -21.07 & -24.31 \\
\hline $\mathrm{CAR}_{1,768}$ & -24.51 & -26.97 & 20 & -25.60 & -25.84 \\
\hline \multicolumn{6}{|c|}{ Panel D: Year 2002} \\
\hline $\mathrm{CAR}_{1,1}$ & 5.00 & -2.59 & 9 & & \\
\hline $\mathrm{CAR}_{1,256}$ & -6.01 & -17.00 & 9 & -7.56 & -12.97 \\
\hline $\mathrm{CAR}_{1,512}$ & -16.11 & -29.48 & 9 & -18.87 & -23.70 \\
\hline $\mathrm{CAR}_{1,768}$ & -40.91 & -43.62 & 9 & -49.32 & -39.22 \\
\hline
\end{tabular}


Market returns were computed for years 2000, 2001 and 2002. Panel B shows positive returns in long term for IPOs listed during 2000, a result, which is different, to the general trend. Even in a long-term period of three years investors have a profit, no matter if they invest during the offer price period or in the end of the first day of trading. On the other hand the positive returns tend to decrease, similar to all the other cases.

The above shows immediately perceptible that during 1999-2000 when CSE experience intense conditions, the returns the investors experienced were impressively high, especially for individuals and institutions that got offers before going public. Carrying into the firms of the 2001-2002 period they offered only negative returns in the long-term period. Additionally buying in the end of the first day of trading proves to be a very bad idea.

In table 6 , firms are segmented by the gross proceeds of the offer. This allows examination of the generality of the negative aftermarket performance of IPOs. A look in table 6 confirms Ritter (1991) finding that there is a tendency for the smaller offers, which have the highest average, adjusted initial returns to have bad aftermarket performance. The Cypriot case becomes interesting, as larger offer seems to offer the worst three years holding period returns. All gross proceeds categories display long run underperformance.

\section{Table 6: Mean performance measures for 75 IPOs categorized by Gross Proceeds} Gross proceeds are measure in Cypriot pounds of 2006-purchase power. Initial returns are computed as $r_{i t}-r_{b t}$ The $t$ here year holding period return is calculated including the initial returns (excluding the initial returns in the brackets).

\begin{tabular}{lccll}
\hline Gross Proceeds & $\begin{array}{l}\text { Average adjusted } \\
\text { initial returns \% }\end{array}$ & $\begin{array}{l}\text { 1 year holding } \\
\text { period returns }\end{array}$ & $\begin{array}{l}\text { 2 years holding } \\
\text { period returns }\end{array}$ & $\begin{array}{l}3 \text { year holding } \\
\text { period returns }\end{array}$ \\
\hline $100,000-250,000$ & 131.06 & $-33.92(-54.0)$ & $-62.29(-69.01)$ & $-70.72(-73.8)$ \\
$250,000-500,000$ & 92.96 & $-22.96(-39.53)$ & $-46.94(-57.58)$ & $-49.98(-60.7)$ \\
$501,001-1,000,000$ & 126.26 & $56.39(-10.04)$ & $-32.21(-52.32)$ & $-68.95(-74.5)$ \\
$1,000,000-13,027,007$ & 85.33 & $-8.21(-46.16)$ & $-63.58(-73.04)$ & $-74.08(-78.9)$ \\
& & & & \\
All & 108.63 & $3.86(-35.26)$ & $-50.41(-62.85)$ & $-66.31(-73.1)$ \\
\hline
\end{tabular}

In table 7 firms are segmented on the basis of their age at the time of going public, computed as the year of the offer minus the year of founding. IPOs are classified in four 
categories the 'baby', 'childhood', 'teenage' and 'mature' IPOs. 'Baby' IPOs have the lowest initial returns mainly due to luck of information which de-motivates investors to take even the risk and invest. Consistent with the notions that risky issues require higher average initial returns Cypriot case indicates that 'childhood' IPOs (4-9 years in operation) offer abnormal returns. The level of initial returns remains high for the 'teenage' firms and tends to decrease in the less risky 'mature' IPOs. Our results are related with Muscarella and Vetsuypens (1989) who document a negative relation between initial returns and age and confirm that age is a proxy for risk.

The aftermarket performance patterns using age as a measure of ex-ante uncertainty can be seen in table 7. It appears that on a three-year long-run basis 'childhood' and 'teenage' IPOs provide the worst returns and proves to be a bad option of investment. Alternatively the 'mature' firms give better aftermarket returns without getting out of the norm of the negative returns. We consider the poor long-term performance of the younger IPOs, which have as in the US case higher market to book ratios than more established firms as an evidence of the overoptimism.

Table 7: Aftermarket Performance Categorized by Age of the Issuing Firm

\begin{tabular}{lccccc}
\hline Age & Sample & $\begin{array}{l}\text { Average adjusted } \\
\text { initial returns \% }\end{array}$ & $\begin{array}{l}1 \text { year holding } \\
\text { period returns }\end{array}$ & $\begin{array}{l}\text { 2 years holding } \\
\text { period returns }\end{array}$ & $\begin{array}{l}3 \text { year holding } \\
\text { period returns }\end{array}$ \\
\hline $0-2$ & 18 & 30.67 & $6.72(-10.23)$ & $-46.87(-50.70)$ & $-66.34(-68.92)$ \\
$4-9$ & 18 & 148.56 & $4.64(-44.01)$ & $-55.37(-69.55)$ & $-69.69(-76.73)$ \\
$10-19$ & 17 & 115.07 & $23.83(-42.58)$ & $-50.43(-67.44)$ & $-71.49(-76.55)$ \\
$20-57$ & 22 & 81.50 & $-14.39(-41.82)$ & $-49.10(-63.22)$ & $-59.53(-70.69)$ \\
& & & & & \\
All & 75 & 108.63 & $3.86(-35.26)$ & $-50.41(-62.85)$ & $-66.31(-73.1)$ \\
\hline
\end{tabular}

The firm characteristics of the Cypriot stock offerings used in this study are presented in Table 8. The mean period between the date of prospectus and first day of trading is 29 days with the maximum being more than $3 \frac{1}{2}$ months. The average market capitalization for Cypriot IPOs is $31.2 \mathrm{~m}$ Cyprus Lira (68.57m USD) and the mean size of the stock offerings is $1.83 \mathrm{~m}$ Cyprus Lira (4.0m USD). Retained ownership, defined as the proportion of shares retained by the pre IPO owners, is high at $87.16 \%$. 


\section{Table 8: Descriptive statistics of independent variables}

(1) TLAG, Time lag between IPO announcement (the date of prospectus and first day of trading) (2) Size, use a control variable to describe if a firm is large or not, (3) AGE, Ln (1+Age) the natural log of the total of one plus the age of the company in years on the listing date (4) UR, Underwriters reputation which gets the value ' 1 ' for reputable underwriters and ' 0 ' for non reputable, (5) H/C, IPO listed in Hot Periods ' 1 ' and IPOs listed during Cold periods gets ' 0 ', (6) OWN, proportion of retained ownership during the going public process

\begin{tabular}{lcccccc}
\hline Variable & Time Lag & $\begin{array}{c}\text { Size } \\
\text { (million) }\end{array}$ & Age & $\begin{array}{c}\text { Underwriters } \\
\text { Reputation }\end{array}$ & Offer Size & $\begin{array}{c}\text { Retained } \\
\text { Ownership }\end{array}$ \\
\hline Mean & 29.12 & 31.2 & 15.43 & 0.6 & 1.83 & 87.16 \\
Median & 25 & 11.0 & 10 & 1 & 0.67 & 95 \\
St Dev & 17.88 & 48.0 & 15.66 & 0.49 & 15.0 & 18.95 \\
Min & 3 & 0.226 & 0 & 0 & 129.4 & 3.75 \\
Max & 107 & 235 & 57 & 1 & 0.03 & 99.72 \\
Sample & 75 & 75 & 75 & 75 & 75 & 75 \\
\hline
\end{tabular}

The correlation matrix in Table 9 suggests that no multi-collinearity problem exists among the independent variables in this study.

Table 9: Correlation matrix of independent variables $(n=75)$

\begin{tabular}{lcccccc}
\hline Variables & $\mathbf{1}$ & $\mathbf{2}$ & $\mathbf{3}$ & $\mathbf{4}$ & $\mathbf{5}$ & $\mathbf{6}$ \\
\hline 1 TLAG & 1.000 & & & & & \\
2.SIZE & $0.213^{*}$ & 1.000 & & & & \\
3.AGE & 0.056 & -0.042 & 1.000 & & & \\
4.UND & -0.107 & -0.043 & -0.122 & 1.000 & & \\
5.HC & -0.053 & 0.010 & -0.051 & 0.004 & 1.000 & \\
6.OWN & -0.128 & 0.169 & 0.123 & 0.048 & -0.034 & -0.003 \\
\hline
\end{tabular}

\subsection{Regression analysis of the determinants of initial underpricing}

Two cross sectional least square regressions of initial excess returns are estimated and summarized in Table 10. The first uses the raw initial returns and the second adapts the general market index searching for adjusted level of underpricing. All standard errors are adjusted for heteroskedasticity. The results show that there is significant relationship between the magnitude of initial underpricing and TLAG indicating that the period between the announcement of the offer price and the first day of trading makes difference on the returns to the investors. This is consistent with the findings of Chowdhry and 
Sherman (1996) and Su and Fleisher (1998) that the time between the IPO announcement day and the first day of market trading affects the underpricing level.

The size of the offering, SIZE, is significant as a determinant of underpricing indicating that the smaller the IPO, the greater the initial return. Similar to Keloharju (1993) we support the rationale that asymmetric information is less and therefore underpricing should be less for bigger firms. In Cyprus, larger IPOs attract a large number of subscribers, and each subscription is of a larger size. Investors are interested in submitting larger orders in larger IPOs, because such IPOs have a more liquid aftermarket, which mitigates the liquidity cost of selling their holding.

The coefficient for AGE is also statistically significant. The negative sign is consistent with the international evidence revealing that history prior going public is a determinant for high initial returns. Our result is consistent with the evidence by Ritter (1984) and Kaneko and Pettway (2003), indicating that firms with long operating history are associated with lower market adjusted initial return.

The finding regarding underwriter's reputation, UND, is negative, as almost every single study in the area has hypothesised. Further to the predicted sign there is no significance of UND with the level of underpricing, an element which shows that reputable underwriters are not powerful enough in the Cypriot market. We find that 'hot market' IPOs experience significantly high initial returns. This evidence is consistent with Ibbotson et al (1986) who report that hot issues markets have average initial returns that sometimes reach unbelievable levels and are associated with increasing volume. This result is consistent with "hot issue" observed by Ritter (1984), Hensler et. al. (2000) and Derrien and Womack (2003).

The coefficient on retained ownership is negative and insignificant indicating that it makes no difference whether the public offering will sell higher proportion of equity in the open market or not. The high-retained percentage of shares by pre-IPO shareholders shows that Cypriots are not ready to loose control of their firms. This opposes Brennan and Franks (1997) finding that on average a large majority of British shares owned by pre -IPO shareholders are sold at the IPO period. 
Table 10: Results of multivariate regression analysis of cross sectional variation in Raw and Adjusted Long term returns as dependent variables in comparison with offer day price for IPOs listed on CSE over the 1999-2002 period

Return $_{i}=\alpha_{0}+\alpha_{1} \mathrm{TLAG}_{\mathrm{i}}+\alpha_{2} \mathrm{SIZE}_{\mathrm{i}}+\alpha_{3} \mathrm{AGE}_{\mathrm{i}}+\alpha_{4} \mathrm{UND}_{\mathrm{i}}+\alpha_{5} \mathrm{HC}_{\mathrm{i}}+\alpha_{6} \mathrm{OWN}_{\mathrm{i}}+\varepsilon$ (1) IR, Initial returns, (2) MAIR, Market adjusted initial returns, (3) R3Y, Raw returns in three years time, (4) ER1Y, Adjusted returns in one year time, (5) ER2Y, Adjusted returns in two years time, (6) ER3Y, Adjusted returns in three years time, (7) R3Y1D, Raw returns in THREE years time from the end of first day of trading (8) ER1Y1D, Adjusted returns in one year's time from the end of $1^{\text {st }}$ of trading (9) ER2Y1D, Adjusted returns in two year's time from the end of $1^{\text {st }}$ day of trading, (10) ER3Y1D, Adjusted returns in three year's time from the end of first day of

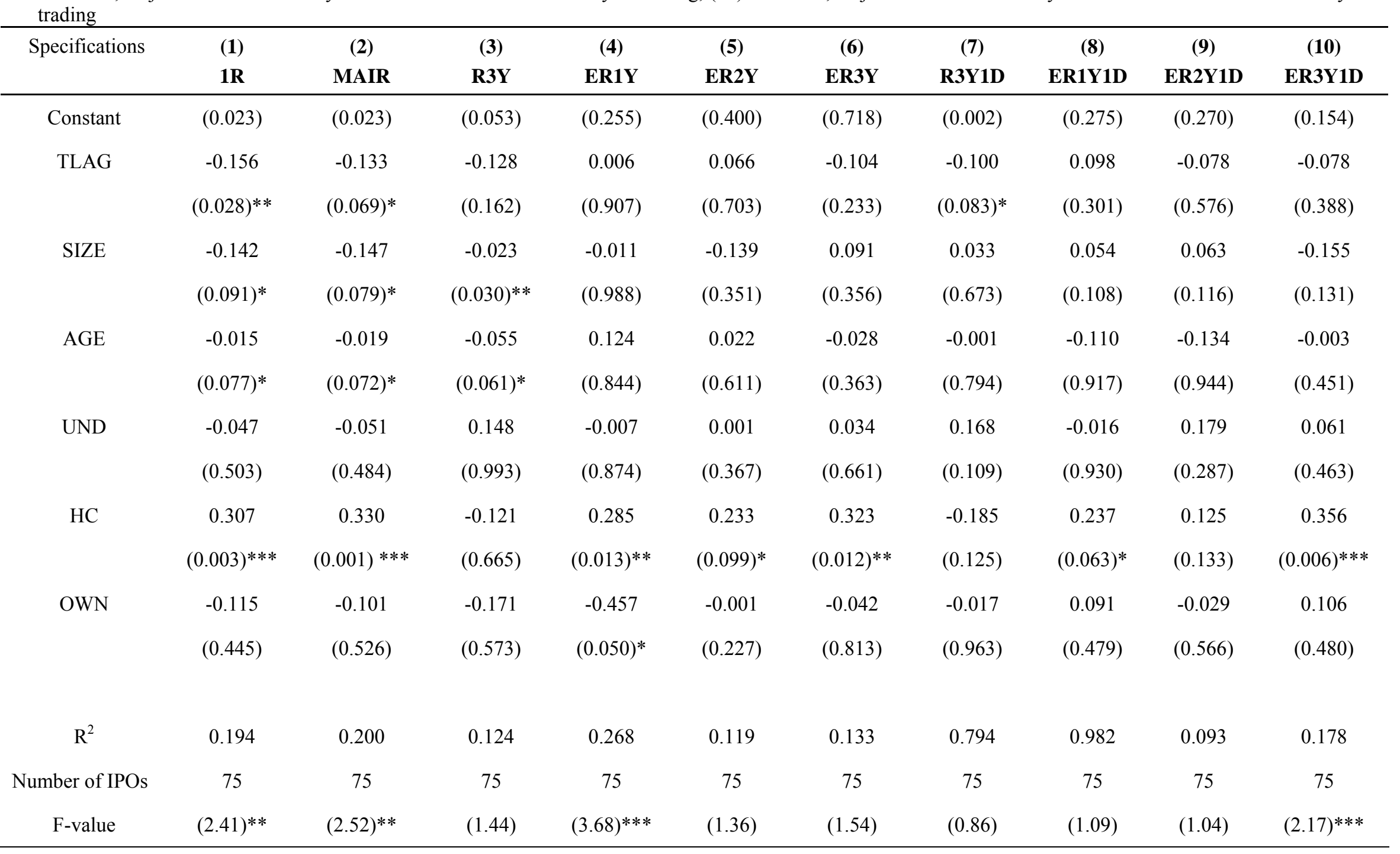




\subsection{Regression analysis of the determinants of long-term performance}

Ritter (1991) presents some evidences that firms with high-adjusted initial returns tend to have the worst aftermarket performance. He attributes his findings to potential overreaction in the market of IPOs. This section examines the long-run performance of IPOs to see whether or not issues have large price declines.

Table 4 documents that IPOs experience negative adjusted long-term returns. This section uses this result and aims to test the determinants of IPO under-performance in a period up to three years. Towards this direction we proceed with regression tests, the results of which are summarized in table 9 .

A glance in the findings reveals significance of three factors with various levels of post IPO performance. The results show that IPOs made on hot market conditions, cause negative returns to investors in one and three year's period. It is obvious that the prices of hot market IPOs in the short term do not reverse in the long term as a result of change in beliefs of investors but due to much optimism that is attributed to the new issues. This reversion in prices relative to the market generates underperformance of IPOs made in the hot market. Our evidence is in line with Ritter (1991) for significant relationship between hot market IPOs and long term underperformance.

Further to the significance in short-term level, SIZE, measured by market capitalization of the firm the year before going public, is a reason for underperformance of IPOs in long term. The three-year raw returns indicate that the small IPOs lead to greater underperformance relative to large IPOs. Pairwise multiple comparisons show that firms in the smallest size group have significantly more negative performance than firms in other size groups in the long term. Furthermore the underperformance seems to be stronger for the smaller firms in three years period showing that it is not a 'small IPO effect' since the average abnormal returns of the largest firms are also negative. Our results for positive relationship between issues size and long run performance is in line with Hanley (1993) and Levis (1993).

The retained ownership of the offering was not found significantly related to initial day returns but it proves a significant factor for one year long underperformance. This finding adds to the literature and mainly to the finding by Leland and Pyle (1977) that firms with greater insider selling should have worse long run performance. It 
matches with Jain and Kini (1994) that the long-run underperformance can be partly explained by the worsening managerial incentives following the IPO.

\section{Conclusion}

This paper studies the underpricing and the long-term performance of 75 IPOs issued in Cyprus between January 1999 and December 2002. Consistent with results from previous studies, and much higher than the returns reported by Ritter (1991) for US IPOs and many other researchers for international IPOs, we find that there is a huge underpricing of Cypriot IPOs, as the average return on the first trading day calculated to be $100.4 \%$. The last figure becomes even higher if we count four outliers that have been excluded from the sample. IPOs are priced substantially below their actual price because of the high level of uncertainty (confusion among the investors), which exists in the market. Investors take advantage and they make very good initial returns once they buy shares in the issue price period.

The long-term performance which includes the first day returns, remains significantly positive for Cypriot IPOs once the focus is up to one year period, but it turns negative for a holding period above the two years. If the first day of trading is excluded then the aftermarket behaviour of Cypriot IPOs becomes negative from the sixth month after listing. A strategy of investing one Cyprus Lira in IPOs at the end of the first day of public trading and holding the shares for a three-year period would have left the investors with only 33 pences. This suggests that it is not a good strategy to hold IPOs for long period.

The results from multivariate regression analysis highlight several significant findings. First, the IPO underpricing is positively related to the number of days between offering period and listing, suggesting that public investors require a larger underpricing if they have to wait longer to trade the new issues. Second, underpricing is negatively related to the size of IPO. To the extent that the market capitalization is an indicator of the length of a firm, our results suggest that the companies with larger market capitalization will have lower level of underpricing. Third, we also find negative relationship between underpricing and the age of IPOs by the time they go public. Ex ante uncertainty is associated with the history of the firms and it seems to make the 
difference, as relative young firms, named as 'childhood' and 'teenage' IPOs, are highly associated with high initial returns. 'Mature' IPOs bring less uncertainty and assist the market to price them near their actual value. Finally, underpricing is positively related to the prevailing market conditions by the time IPOs goes public, suggesting that the large underpricing is due to 'hot issue' markets. This is consistent with Loughran and Ritter (2002) who find the performance of the market to be significantly related to the magnitude of underpricing in the U.S.

We also examine the variables, which affect the long-term performance of IPOs. Multivariate analysis based on a one to three year period, reveals significance of three factors. Initially the IPO aftermarket underperformance is negatively related to the size of the firms, suggesting that large IPOs should expect less negative future returns. Similar to the short-term, market condition plays an important role in the aftermarket. The IPOs with excess initial returns tends to offer extremely negative in the long term.

The question that is raised is how to interpret the significantly long-run underperformance that follows the IPOs. One interpretation might be that large information asymmetry causes the market to be irrationally optimistic about the initial public offerings. This fact leads investors to pay too much in the immediate aftermarket period for an IPO, and then discover the mistake in the following years as argued by Ritter (1991) who concludes that the offering price of underperformed IPO stocks is not too low but too high. Although our results are consistent with this fact, this simple irrationality during IPOs does not seem to explain the whole phenomenon.

Despite the fact that the findings of the existing study is in line with the international literature, it is almost essential any further study on Cypriot IPOs. The period of this study presents some unique characteristics as the stock market boom does not represent the actual increase in the value of shares. The 'bubble effect', which was followed, had as a result excess returns to be taken by the investors. The stock market after the phase of its euphoria experienced a strong downward period. Its main characteristics were the high uncertainty among the investors, the lower level of daily trading in the stock market and the negative aftermarket returns. 


\section{References}

Affleck-Graves, J., S. Hedge, and R. Miller, 1996, Conditional price tends in the aftermarket for initial public offerings, Financial Management 25, 25-40.

Aggarwal, R. Leal, and L. Hernandez, 1993, Activities by underwriters performance of Initial public offerings Latin America Financial Management, 22, $42-53$.

Aggarwal, R., R. Leal, and L. Hernandez, 1993, The aftermarket performance of initial public offerings in Latin America, Financial Management 22, 42-53.

Ahmad-Zaluki, N. , K. Campbell, and A. Goodacre, 2004, The long run share price performance of Malaysian Initial Public Offerings, working paper, University of Stirling.

Allen, F. , and G. Faulhaber, 1989, Signaling by underpricing in the IPO market, Journal of Financial Economics 23, 303-323.

Allen, M. , R. Rutherford, and T. Springer, 1993, The wealth effects of corporate real estate leasing, Journal of Real Estate Research 8, 567-578.

Alvarez, S., and V. Gonzalez, 2001, Long run performance of initial public offerings (IPOs) in the Spanish capital market, European Financial Management Association (Lugano).

Ansotegui, O., and F. Fabregat, 2000, Initial Public Offerings in Spanish stock exchange, Working paper, ESADE.

Aussenegg, W., 2000, Short and long run performance of Initial public offerings in the Austrian stock Market, Working Paper, Vienna University of Technology.

Banz, R., 1981, The relationship between return and market value of common stocks, Journal of Financial Economics 9, 3-18.

Barry, C., and R. Jennings, 1993, The opening price performance of initial public offerings of common stock, Financial Management 22, 54-63.

Beatty, R., and J. Ritter, 1986, Investment banking, reputation, and the underpricing of initial public offerings, Journal of Financial Economics 15, 213-232.

Beatty, R., and I. Welch, 1996, Issuer expenses and legal liability in Initial Public Offerings, Journal of Law and Economics 34, 542-602.

Benveniste, L. , A. Ljungqvist, Wilhelm Jr., and X. Yu, 2003, Evidence of information spillovers in the production of investment banking services, Journal of Finance 58, 577-608.

Booth, J., and L. Chua, 1996, Ownership dispersion, costly information, and IPO underpricing, Journal of Financial Economics 41, 291-310.

Brennan, M., and J. Franks, 1997, Underpricing, ownership and control in initial public offerings of equity securities in the UK, Journal of Financial Economics 45, 391-413.

Cai, J., and K. Wei, 1997, The investment and operating performance of Japanese initial public offerings, Pacific-Basin Finance Journal 5, 389-417.

Carter, B., F. Dark, and R. Singh, 1998, Underwriter reputation, initial returns, and the long run performance of IPO stocks, Journal of Finance 53, 285-311.

Chan, L., Y. Hamao, and J. Lakonishok, 1991, Fundamentals and stock returns in Japan., Journal of Finance 37, 389-417.

Chemmanur, T., and I. Paeglis, 2005, Management quality, certification, and initial public offerings, Journal of Financial Economics 76, 331-368.

Chowdhry, B., and A. Sherman, 1996, The winners curse and international methods of allocation Initial public offerings, Pacific -Basin Finance Journal 4, 15-30.

Daniel, K., and S. Titman, 1997, Evidence on the characteristics of cross-sectional variance in common stock returns., Journal of Finance 52, 1681-1714.

Daniel, K., S. Titman, and K.C. Wei, 2001, Explaining the cross-section of stock returns in Japan: factors or characteristics?, Journal of Finance 56, 743-766.

Davis, J., 1994, The cross-section of realized stock returns: the pre-COMPUSTAT evidence., Journal of Finance 50, 1579-1593.

Davis, J., E. Fama, and K. French, 2000, Characteristics, covariance, and average returns: 1929 to 1997 , Journal of Finance 50, 1579-1593.

Derrien, F., and K. Womack, 2003, Auction vs Book-building and the control of underpricing in Hot IPO markets, Review of Financial Studies 16, 31-61. 
Dhatt, M., Y. Kim, and U. Lim, 1993, The Short-Run and Long-Run Performance of Korean IPOs: 198090, Working Paper, University of Cincinnati.

Drake, K., and M. Vetsuypens, 1993, IPO Underpricing and insurance against legal liability, Journal of Financial Management 22, 64-73.

Espenlaub, S., and I. Tonks, 1998, Post-IPO directors' sales and reissuing activity: An empirical test of IPO signaling models, Journal of Business Finance \& Accounting.

Fama, E., and K. French, 1992, The cross section of expected stock returns, Journal of Finance 47, 427465.

Firth, M., 1997, An analysis of the stock market performance of new issues in New Zealand, Pacific-Basin Finance Journal 5, 63-85.

Garfinkel, J., 1993, IPO Underpricing, insider selling and subsequent equity offerings: Is underpricing a signal of quality?. Financial Management 22, 74-83.

Grinblatt, M., and C. Hwang, 1989, Signaling and the price of new issue, Journal of Finance 44, 47-58.

Hameed, A., and G. Lim, 1998, Underpricing and firm quality in Initial Public Offerings: Evidence from Singapore, Journal of Business Finance \& Accounting.

Hanley, K., 1993, The underpricing of initial public offerings and the partial adjustment phenomenon, Journal of Financial Economics 34, 231-250.

Hansen, R., and P. Torregrosa, 1992, Underwriter compensation and corporate monitoring, Journal of Finance 47, 1537-1555.

Hensler, D., M.. Herrera, and L. Lockwood, 2000, The performance of initial public offerings in the Mexican stock market, 1987-1993, Journal of International Money and Finance 19, 93-116.

Hin, T., and H. Mahmood, 1993, The Long-Run performance of Initial Public Offerings in Singapore, Securities Industry Review 19, 47-58.

Hingorani, A., K. Lehn, and A. Makhija, 1997, Investor behaviour in mass privatization: The case of the Chech voucher scheme, Journal of Financial Economics 44, 349-396.

Huang, Y., 1999, The price behavior of Initial Public Offerings on the Taiwan Stock Exchange, Applied Finacial Economics 34, 153-175.

Ibbotson, R., and J. Jaffe, 1975, Hot Issue Markets, Journal of Finance 30, 1027-1042.

Jain, B., 1994, The underpricing of 'unit' initial public offerings, The Quarterly Review of Economics and Finance 34, 309-325.

Kaneko, T., and R. Pettway, 2003, Auctions versus book building of Japanese IPOs, Pacific-Basin Finance Journal 11, 439-462.

Keloharju, M., 1993, The winner's curse, legal liability, and the long-run price performance of initial public offerings in Finland, Journal of Financial Economics 34, 251-277.

Kooli, M., and J. Suret, 2002, The aftermarket performance of Initial Public Offerings in Canada, Working Paper.

Lakonishok, J., A. Shleifer, and R. Vishny, 1994, Contrarian investment, extrapolation, and risk., Journal of Finance 49.

Lee, P.., Stephen L. Taylor, and Terry S. Walter, 1996, Australian IPO pricing in the short and long-run, Journal of Banking \& Finance 20, 1189-1210.

Leland, H., and D. Pyle, 1977, Information Asymmetry, financial structure and financial structure intermediaries, Journal of Finance 32, 317-387.

Levis, M., 1993, The long-run performance of IPOs: The UK experience 1980-1988, Financial Management 22, 28-41.

Ljungqvist, A., 1997, Pricing initial public offerings: Further evidence from Germany, European Economic Review 41, 1309-1320.

Loughran, T., and J. Ritter, 1995, The new issues puzzle, Journal of Finance 50, 23-51.

Loughran, T., and J. Ritter, 2002, Why don't issuers get upset about leaving money on the table of IPOs?, Review of Financial Studies 15, 413-443.

Loughran, T., J. Ritter, and K. Rydqvist, 1994, Updated 2003, Initial public offerings: International insights, Pacific-Basin Finance Journal 2, 165-199.

Loughran, T., J. Ritter, and K. Rydqvist, 2006, Initial public offerings: International insights, Pacific-Basin Finance Journal 2, 165-199.

Lowry, M., and W. Schwert, 2002, IPO market cycles: Bubbles or sequential learning, Journal of Finance 57, 1171-1200.

Lyn, E. , and E. Zychowicz, 2003, The performance of new equity offerings in 
Hungary and Poland, Global Finance Journal 14, 181-195.

McGuiness, P., 1993, The Post-Listing Return Performance of Unseasoned Issues of Common Stock in Hong Kong, Journal of Business Finance and Accounting 20, 167-194.

Nanda, V., and Y. Yun, 1997, Reputation and financial intermediation: An empirical investigation of the impact of IPO mis-pricing or underwriter market value, Journal of Financial Intermediation 6, 3963.

Nazir, N.., and R.. Zin, 1998, An examination of the underpricing of Initial Public Offerings (IPOs) in Malaysia: 1990-1995, Finance Conference Kuala Lumpur, Malaysia.

Ritter, J., 1984, The hot issue market of 1980, The Journal of Business 57, 215-240.

Ritter, J., and I. Welch, 2002, A Review of IPO Activity, Pricing, and Allocations, The Journal of Finance.

Rocholl, J., 2004, How does the underwriters match allocation and demand in IPO Bookbuilding, Working Paper.

Rock, K., 1986, Why new issues are underpriced, Journal of Financial Economics 15, 187-212.

Su, D., and B. Fleisher, 1998, Explaining IPO initial returns in China, Emerging Market Quarterly 2, 1-16.

Thomadakis, S., C. Nounis, and D. Gounopoulos, 2006, The Long Term Performance of Initial Public Offerings in the Athens Stock Exchange (1994-2002), working paper.

Tinic, S., 1988, Anatomy of IPOs of the common stock, Journal of Finance 44, 723-739.

Welch, I., 1989, Seasoned offerings, limitations costs and the underpricing of initial public offerings, Journal of Finance 44, 421-449.

Welch, I., 1992, Sequential sales, learning and cascades, Journal of Finance 47, 695-732.

Yilmaz, M., and R. Bildik, 2005, The market performance of Initial Public Offerings in the Istanbul Stock Exchange, Working paper, Istanbul Stock Exchange. 